\title{
Impact of Work Overload and Work Hours on Employees Performance of Selected Manufacturing Industries in Ogun State
}

\author{
Clement Uchechukwu Ukwadinamor Ph.D.,FCE ${ }^{1}$ and Adedara Subomi \\ Oduguwa $\mathrm{PhD}^{2}$ \\ Department of management and Accounting, Lead City University, Ibadan Oyo State.
}

\begin{abstract}
Work overload has been identified as an indicator of migraine by neurologists, which has a negative effect on their well-being and performance at work. The competitive nature of the job market in developing countries like Nigeria only adds to the deteriorating work-life balance as employees strive for competitive advantage at the expense of their well-being and family life.

Today's worker, at the end of a working day is fully exhausted, due to challenged responsibilities and the culture of long working hours. For example, the insistence of 8am to 5 pm working hours have been identified as a major cause of increased medical problems such as diabetes, hypertension, psychological and attitude problems, aches and pains among other ailments.

The main objective of this study was to determine effect of work overload and work hour on employee's performance in selected manufacturing industries in Ogun State. Descriptive survey research design was used with sample size of four hundred employees of selected manufacturing companies in Ogun State.Both work overload and work hour has been found to play a huge role in the quality of employees' family life, such as marital satisfaction, relationship with children and spouses, which in return affects their job commitment. The findings showed that work overload to employees' performance $\left(F_{[1,473]}=22.752, P<0.05, R^{2}=0.0457\right.$ and work hour to employees' performance $\left(F_{[1,472]}=51.238, P<0.05, R^{2}=0.0473\right)$. The study concluded that, work-life- balance idea is connected with real aids for an organization. Therefore, the study recommended that social and psychological life of every employee should be put to check in order for employees to be effective and efficient on their jobs.
\end{abstract}

Keywords: Employees performance, Work hours, Work-life balance Work overload

\section{Introduction}

The line between work and life has been subject of interest amongst scholars and practitioners nowadays. Several factors have been found to have sparked this interest and these include changes of demographic composition in the labor market and in the amount and pace of work, and increases in work hours (Helmle, 2019). A person can live a life that is happy, healthy and successful when there is work-life Balance. Work-life Balance has indeed become a primary concern to those wishing to have good quality of life (Breitenecker\&Shah,2018). The notion of Work-life Balance has been described by many, and for the majority, work encompasses thevenue of official tasks to be accomplished by individual while executing a given job. Accordingly, life encompasses a collection of activities not related to work for instance household chores and childcare. In this regard, balance is achieved when there is harmony between work and life. (Semlali\& Hassi,2016). Since the last decades, the concept of Work-life Balance has been viewed as crucial to both organizations and people, and it has indeed been found to greatly contribute in the improvement of productivity of employees which in turn impacts the performance of organizations in positive manner (Guthrie, 2018). Effective policy of work-life balance embraced by the organization allows the employees to socialize with the community while assuring that cost and turnover are under control and productivity is improved (Helmle,2019).

It is yet to be affirmed when it comes to the association between the happiness of worker and productivity in the workplace. Still, the common consensus is that a happy employee is a productive employee (Joo \& Lee, 2017; Abualoush,2017). For human resource management, to keep employees healthy and able to work long hours efficiently is a great challenge. One indicator of good mental health is engaging the employees at work (Nielsen, 2019). The well-being of employee, both physical and mental, is very important, and as stressed in studies, employee well-being impacts the success of organization. For instance, it has been reported that employees who feel good and deal with less stress at work and at home are more likely to experience satisfaction towards their work, and this can significantly affect their well-being and also their organization (Koubova \& Buchko, 2017). Even though the factors of engaging at work, career satisfaction, and subjective 
Impact of Work Overload and Work Hours on Employees Performance of Selected ..

well-being are showing judicious relationships with each other while also demonstrating inclination towards showing consistency within individuals over time, among scholars and practitioners, employee engagement is their major concern. This owes to the fact that engaged workers appear to have greater level of motivation, and demonstrate greater level of involvement in their jobs and organizations (Shafferet, 2016). These employees are also more productive, and have greater level of readiness in giving more than what they are supposed to in contributing to the survival and success of their organization (Shafferet,2016; Obeidat, 2018).

Work-life balance and happiness is still insufficiently studied although this subject has been receiving increasing attention from scholars. Relevantly, employees spend significant amount of their time working. Still, past studies on life satisfaction or well-being were focusing on non-work populations (e.g., patients, children, students, and/or adolescents). As such, this study is of the view that in the domain of management, the lack of attention on employee well-being has become a critical gap in the extant research. Meanwhile, the negative behavior demonstrated by employee can be triggered by the increase of work stress (Emslieand \&Hunt,2020). In reality, as reported by Mullen and Kelloway (2018), failure in performing tasks, turnover, and absenteeism are now becoming common in the workplace, and all these are compromising the effectiveness and development of the organization. It is the obligation of the organization to play a major role in attaining and sustaining employees that are healthy, well-trained, and capable on a long-term basis (Nielsen, 2019). Further the purpose, organization needs to delineate an environment in which employees can grow themselves and discern the well- being (Nielsen, 2019). Employees are obliged demonstrate hard work and in the course, they often have to work extra hours so that they could fulfill their financial obligations, which leads to a disparity between work and family. Long working hours cause job-to-home spillover to increase and this may impact negatively on job performance of employees and productivity and profits of organizations. This implies the presence of gap which this study attempts to Fill gaps in previous studies, particularly in terms of happiness of employees and attention to their family in order to increase creativity and innovation in terms of performance (of the employees). It is on this note this study focuses on how work-life balance affects the performance of employees in setting where work-life balance is a challenge such as Manufacturing Industry in Ogun State.

\section{Statement of the Problem}

There has been lot of debates on work life balance as a predictor of employee performance; however, it has not received adequate attention from corporate managers in Nigeria and Africa. The manufacturing sector recorded a general decline between January and November 2016 according to the central bank of Nigeria as indicated by the Purchasing Managers Index (PMI) which stood below 50 index points during this time. Employee performance has been established in literature as an indicator of organizational performance and the Nigerian manufacturing industry typifies this scenario. Several factors have been attributed to the decline in the employee performance in the manufacturing industry. Crucial among them are: Poor work-life balance programmes, poor leadership from top leadership, outdated technology, poor policies, clash of values and bullying or harassment. Of all these aforementioned problems, this study focused on the issue of work-life balance as it affects employee performance. The competitive nature of job market in developing countries like Nigeria only adds to the deteriorating work-life balance as employees strive for competitive advantage at the expense of their well-being and family-life. There are growing concerns that the quality of work and family-life of employees are declining, acts as a precursor to poor contributions and poor performance at work (Orogbu et al., 2015).

Neurologists have identified work overload as an indicator of migraine, which has a negative effect on their well-being and performance at work ("Work overload", 2017). Work overload has also been linked with decreased job satisfaction and continued complaints about work-life related stress (Shah, 2014). Goveas (2011) argued that today"s worker, at the end of a working day is fully exhausted, due to challenged responsibilities and the culture of long working hours. For example the insistence of $8 \mathrm{am}$ to $5 \mathrm{pm}$ working hours have been identified as a major cause of increased medical problems such as diabetes, hypertension, psychological and attitude problems, aches and pains among other ailments. These failing medical conditions directly affect employee performance and consequently lead to decline in organizational performance (Fapohunda, 2014). Dzurizah (2014) posited that the inability of employees to have control over their working hours have made them become ineffective marriage partners, parents and citizens.

\section{Objective of the Study}

This study investigated the effect of work overload and work hours on employee"s performance in selected manufacturing industries in Ogun State. The specific objectives are to:

i. determine the effect of work overload on employees" performance in selected manufacturing industry in Ogun State.

ii. examine the effect of work hourson employees" performance in selected manufacturing industry in Ogun State? 
Impact of Work Overload and Work Hours on Employees Performance of Selected ..

\section{Hypotheses}

$\mathrm{Ho}_{1}$ : Work overload has no significant effect on employees" performance in selected manufacturing industry in Ogun State.

$\mathrm{Ho}_{2}$ : Work hours has no significant effect on employees" performance in selected manufacturing industry in Ogun State.

\section{Work-Life Balance}

\section{Review of Literature}

The notion of work-life balance gained high importance as changes in the work place such as advances in information technology and information overload that requires quick response puts increasing pressure on employees (Hye, 2014). The shift away from the image of traditional family towards an increasing appearance of single parent families and greater participation of women in the labour force represent factors requesting a greater work-life balance among employees (Hye, 2014). Work-life balance was first used to describe the trend of individuals spending more time on work and less time on other aspects of their life (Khan, 2013). It wasn"t until the mid-60s that the subject of work-life balance became the subject of interest among scholars. For instance, Kahn (1964) concluded that for employees, work-family conflicts are a substantial stress source. Relevantly, the notion of equilibrium between family and professional life (work-family balance) is recently employed when referring to the successful development of both domains. At present time, in order to fine-tune the organizational structures to the needs of the employees or to respond to government regulations with respect to gender equality, integration, and protection of families, a lot of organizations dedicate their resources to the initiatives of work-life (Susana \& Ramón 2019). As has been emphasized by a number of scholars, at present time, it is likely to have employees that demand the initiatives of work-life balance from the organization. Such demand has been closely linked to the increasing commonness of dual-career couples, family or dependent accountabilities, or the wish to devote more time to friends or enjoy leisure undertakings (Lavoie, 2019).In studies on work-life, the focal point has been the effect of organizational services and policies that are established for providing assistance to employees regarding the conflicts that occur between their work and their life. Accordingly, the extant literature attempted to comprehend the role played by organizations to help reduce the conflict experienced by the employees that occurs from the demands of work and the role they are obliged to play at home(Emslie\& Hunt, 2020; Hon \& Chan,2019). As evidenced from the findings, employees with access to services including flexible schedules, childcare, parental leave, and support from supervisor appear to be more likely have less conflicting work-life, greater job satisfaction, less stress, and are less inclined to want to quit (Helmleet,2018). In research on the issue regarding work-life, gender has also been explored, particularly with respect to how the roles and expectations of gender impact the perceptions regarding work and family roles. Here, as evidenced by the findings, in certain situation, gender expectations in a situation impact how far individuals feel incompatibility between work and life roles, and this can cause the perceived level of stress and the perceptions of conflict between the roles of work and life to increase (Helmleet, 2018; Lawson, 2019).

The management of work-life balance and/or work-family conflict interest of employees has been found to be among the primary aspects to be addressed by the organization as a way to preserve human resources (Au and Ahmed, 2018). Work-life balance encompasses a balance between two entirely separate roles performed by a person namely the roles of work and the roles of family, and to holder of the roles, both bring satisfaction (Shaffer, 2016).The benefits of work-life canimprove both the life quality of employees and the effectiveness of the organization. Hence, there appears to be countless delineations regarding work-life balance, but all appear to be in agreement that work encompasses a group of formal tasks completed by an individual while occupying a given job. Life comprises a group of activities not associated with work such as household chores, care of elderlies and care of children (Anwar, 2019). Emslieand Hunt (2009) stated that balance is attained when the domain of work and that of life are in harmony. Work-life balance is about a person"s capacity irrespective of age or gender in successfully combining work and household accountabilities. Within this context, work becomes a term that can be regarded as paid employment and also free work done for an employer.

Conversely, the notion of "life" is not related to work and it can be broken down into free time used in doing leisure activities, and family time (Lawson,2019). Accordingly, the concept of work-life balance defines the amount of time available to an employee in balancing between family and the demands of work. Work-life balance encompasses an employee"s time-sharing ratio between work and family. When there is imbalance between work and family, whether too much on work or too much on family matters, stress and negative work attitudes can occur and these can lead to burnout(lawson, 2019 ). In the work of Grzywacz and Carlson (2007), work-life balance is described as the achievement of role-related expectations exchanged and shared between people and their role-related partners in the arena of work and family. Meanwhile, work-life balance was addressed by Greenhaus and Allen (2017) as the degree to which the effectiveness and satisfaction experienced by a person in terms of his work and family roles are attuned to his role priorities of life at certain point in time. 
Impact of Work Overload and Work Hours on Employees Performance of Selected ..

Effective Work-Life Balance is underpinned by two applicable primary concepts namely the day-to-day accomplishment and enjoyment. Achievement is the successful completion of something particularly after a series of diligent attempts or being given what is desired. With respect to the notion of enjoyment, it does not denote happiness. Rather, it denotes pride, satisfaction, celebration, joys of living as well as a sense of wellbeing. In life, achievement and enjoyment have close linkage in terms of value. In other words, a person has to have both. This is the reason why those who are deemed successful do not feel happy or are not as happy as they are supposed to be (Hon \& Chan,2019).

Several authors have attempted to explain and emphasize the interconnection of work and personal life in organizational settings, namely: (1) the compensation implies that employees tend to compensate for low work or personal life satisfaction by seeking contentment in other domain; and (2) the spillover view indicates that job

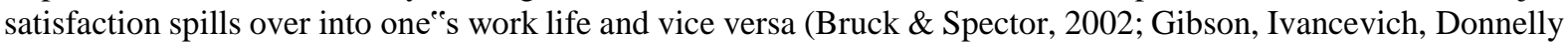
\& Konopaske, 2006). Greenhaus, Colins and Shaw (2003) explored and measured three aspects of work-life balance namely: (1) Time balance, which concerns the amount of time given to work and non-work roles; (2) Involvement Balance, meaning the level of psychological involvement in, or commitment in work and non-work roles; and (3) level of satisfaction with work and non-work roles.

For the purpose of this study, definition of work-life balance proposed by Barrera (2007) was adopted because it is broad and encompassing. Work-life balance is employers working constructively with their employees to put in place arrangements, which takes into account the needs of the business as well as the nonwork aspects of employees" lives (Barrera, 2007). The definition consists of both employees and policies and practices and acknowledgment that work-life balance can only be achieved as a joint effort between employers and employees. The increasingly competitive nature of the labour market creates an environment where employees engage in more work than they have the resources to do satisfactorily. The consequent reduction in performance has been widely reported in literature leading to an increase in the investigation of the effects of work overload. Elloy and Smith (2003) distinguished between domestic overload where demands created by housekeeping tasks exceeds the amount of time available to complete them, and work overload, where one does not have enough time to complete work tasks. According to Shah (2014) work overloads occurs when an individual engages in multiple roles with unlimited demands causing role strains and role conflict because the demands and expectations the individual has to fulfil are scarce and limited. Duxbury, Higgins and Lyons (2010) defined work overload as when an individual has too many role statuses such as parents, student, child, friend, spouse, worker and community leader, making it difficult to meet the demands of each status to the satisfaction of all the role partners and the satisfaction of self.

Work overload is conflict occurring when the level of demand exceeds a person"s available resources, when the person has too many tasks that require attention (Willow, 2006). Work overload is related to the total time demands placed on an individual by his or her multiple roles (Sousa, 2013). Work overload occurs when an individual has too many work demands given the limited time available to satisfy them (Bhowte \& Paturkah, 2013). The extent of Work overload would depend on the level of demand imposed upon a person and other factors in the person"s environment (Willow, 2006).Elloy and Smith (2003) postulated the existence of two types of work overload; Quantitative and Qualitative. They posited that qualitative overload refers to a situation where task is too difficult to complete, while quantitative overload is experienced when there are too many task to be done. Literatures have revealed that work overload is a key predictor of employee performace. High levels of work overload means that an individual has too many roles demands and obligations, but is unable to perform them all effectively and it has an effect on the equilibrium of work and life activities. Frone, Yardley and Markel (1997) reasoned that work overload represents a strain-based predictor, because having too much to do and too little time is likely to lead to emotional exhaustion because there is no balance and it negatively affects performance of employees.

Shah (2014) in his study posited that most employees are engaged with too much task because of the competitive nature in securing job, fear of the unknown, and accolades at the detriment of their wellbeing. Osman (2012) posited that when employees are taxed beyond their understanding, competence, talent and available working hours they tend to be less productive, job burnout, poor customer delivery, experience high family conflicts, emotional stress and exhaustion, and workplace accident.

\section{Employee Performance}

Employee Performance can be described as responses in the form of behaviors reflecting what has been learned by the employee or the kind of training that the employee has received; it encompasses the outcome of the mental and psychological capabilities (Faiza and Nazir, 2015). Employee Performance is a concept that is increasingly popular amongst scholars of management sciences, as employee performance is vital to both individual and the organization. Employee Performance contributes to the overall betterment of the processes of the organization particularly in terms of efficiency and productivity (Abualoush, 2018). Employee performance has linkage to the activities and tasks employees carry out in effective and efficient manner, and it also dictates how much employees contribute to the organization and among the contributions of employees are output 
Impact of Work Overload and Work Hours on Employees Performance of Selected ..

quantity, work attendance, and accommodating attitude (Abualoushet, 2018b). Furthermore, the financial or nonfinancial outcomes of the employee which are closely related to the performance and success of the organization is also reflected by employee performance (Anitha, 2019). In regards to the notion of performance, it is measurable using different mechanisms (Faiza \& Nazir,2015), and in general, performance encompasses what is done or not done by employee. It entails the full outcome or success of a person during specific periods of duty as opposed to the predetermined and established standard of work andtargets or criteria (Abualoush,2018; Pawirosumarto, 2017). Performance is the product of the capacity of employee, multiplied with support and effort. Hence, reduction or nonexistence of one factor will cause decrease in performance (Pawirosumaro, 2017).

\section{Theoretical Review}

\section{Inter-Role Conflict Theory}

Inter-role conflict theory refers to what occurs when meeting the demands in one domain makes it difficult to meet the demands in the other domains (Greenhaus \& Beutell, 1985). The underlying assumption of this theory is that the extent to which there is consensus on role definition may be an important dimension affecting the dynamics of social systems (Bernard, 1977). Secondly, this theory assumes that the degree of consensus between role definers (top level administration) as perceived by the employees may be an important factor affecting his behavior.In literature, inter-role conflict theory has also been termed opposition or incompatibility theory (Edwards. 2000). Greenhaus and Beutell (1985) posited that an individual encounters role conflict when expectations or demand from one role interfere with an individual"s capacity to meet expectations or demands of another role. They described propositions where constructs are in conflict in relation to Time, Role strain and Specific behaviors, as follows: pressures must come from both work and family; self- identification with roles is necessary; role salience moderates relationships and is positively related to conflict level; conflict is strongest when there are negatives associated with non-compliance; directionality is based on conflict source; conflict is related to career success and stage; external support is related to conflict.Employees experiencing work overload are unable to meet other life demands due to excessive work demands. The inter- role conflict theory clearly explains this phenomenon as it describes a situation where trying to meet the demands of a domain makes it difficult to meet demands of other domains. Hence this study investigates the effect of work overload against the backdrop of inter-role conflict theory.

\section{Spillover Theory}

Several researchers suggested that workers carry emotions, attitudes, skills and behavior that they establish at work into family life (Belsky, Pery-Jenkins \& Crouter, 1985; Kelly \& Voydanoff, 1985; Piotrkowski, 1979; Tsai, 2003). The underlining assumption of spillover theory is that the consequence of spillovers from one domain to the other is always positive or negative (Hill, Ferris \& Martinson, 2003). It has been documented in research that when work and family are rigidly structured in time and space, the spill over in term of time, energy and behavior is negative (West, 2001). The spillover approach proposed that experience in one role affects experiences in the second role. This theory recognizes the influence of the two domains on each other. It states that increased satisfaction (or dissatisfaction) at work leads to increased satisfaction (or dissatisfaction) at home. The behavior, mood, skills and values from one role can spillover to the second role. Spillover may occur in two conditions. Firstly, when there is a similarity between work and any other domain (Edwards et al. 2000). E.g. stress at workplace spills over to the family domain and the individual displays irritable mood in the family. Spillover theory has been termed as generalization, continuation, extension, familiarity, and similarity (Edwards et al. 2000; Staines, 1980 \& Zedeck, 1992 as cited in Schultz, 2009).

There are two interpretation of spillover (Edwards et al. 2000): (a) the positive association between life and work satisfaction and life and work values and (b) transference in entirely of skills and behavior between domains such as when fatigue from work is experienced at home or when family demands interfere with work demands. Thus, spillover can be both positive and negative. Positive spillover refers to fact that satisfaction and achievement in one domain may bring along satisfaction and achievement in another domain. Negative spillover refers to the fact that difficulties and depression in one domain may bring along the same emotion in another domain $(\mathrm{Xu}, 2009)$.

\section{Emprical Review}

Mcnall, Aline and Jessica (2010) investigated the relationship between the availability of two common types of flexible arrangements (flextime and compressed work week), work to family enrichment and, in turn, the relation between work to family enrichment and (a) job satisfaction and (b) turnover intentions. Clare and Deirdre (2010) highlighted an unexpected consequence of adopting flexible working practices. Away from the expected improvement in employee performance due to flexible work options, the researchers presented evidence of work intensification being experienced by employees working reduced hours and employees 
Impact of Work Overload and Work Hours on Employees Performance of Selected ..

working remotely. Clare and Deirdre (2010) also presented evidence that employees on flexible working arrangements record higher levels of job satisfaction and organizational commitment than their nonflexible counterparts. While most studies highlight the benefits of flexible working arrangements vis-a-vis employee performance, some scholars have presented evidence of unanticipated reactions to availability of flexible working at organizations. Dex and Smith (2007) for instance, affirmed that a lot of workers do not fancy becoming visible as special cases or requiring special treatment to their colleagues. This perception sometimes hinders such employees from utilizing the available flexible working opportunities which defeats the purpose of such provisions. Allen (2009) stated that co-workers tend to perceive employees who make use of work-life balance programs in organizations as less committed. It is therefore important for organizational leadership to ensure these perceptions are corrected so as to get the best from adopted flexible working practices.Umer and Akram (2011) investigated the effect of employee retention on employees in the industry. Findings showedthat career development has shown a strong relation with turnover of workers. When industry gives chances for development and improvement for example diverse courses and instructive sponsorship then workers are more fulfilled by their employment. Hence, when workers perform better, they fill accomplished and fulfilled. Ahmed (2015) in a study exploring the impact of career development on employee commitment and engagement shows that there is a strong correlation between career development and how committed an employee"s attach themselves with the organization. Hence, when employees have career development option they are more committed(Roselina \& Roslina2013).

Kristie (2017) examined the relationship between work overload and employee performance. His study revealed that there was a significant positive effect of the implication of overload and employee performance. Sobia and Yasir (2014) investigated the effect of work overload on job satisfaction and the effect of job satisfaction on employee performance and employee engagement. The results of the study revealed a negative relationship exists between work overload and job satisfaction. A positive relationship was identified between job satisfaction and employee performance. A positive relationship was identified between job satisfaction and employee engagement.

Abdul, Nafees and Imran (2015) explored the impact of career development on employee performance in the petroleum sector in Pakistan. Findings revealed that career development is a key predictor of employee performance. An employee can be more productive when career development options are available for use even when suffering from overload. Saud, Tulus, Asri, Hunik and Mugi (2017) also investigated the impact of career development on employee performance. Findings showed a significant effect on employee performance and it revealed that organization capitalizes on career development in order to have an increased productivity on employee performance. Sharjeel and Saba (2013) in an empirical study of Pakistani academic sector argued that there is a strong impact of career development on employee performance. When employees in the academic sector are given opportunity for career development, studies reveals that they perform beyond expectation. Ami (2016) examined the influence of career development on employee performance. Result revealed that employees strive to perform better when they see that organizational support are given to achieve career development

\section{Methodology}

Descriptive survey research allows the use of quantitative and qualitative techniques in other to describe events and sometimes make inferences (using inferential statistics) from collected data. Generally, the quantitative approach has the characteristic of measuring objective facts using variables where data is separated from theory, statistically analyzed and emphasized with its reliability (Neuman, 2006). The population of the study comprised of staff of Unilever Plc, Lafarge Cement, Reckitt Benckiser, GZ Industries Limited and Evans Medical Plc. The total population was 26754 (as obtained from the websites of the selected companies as at January 2019). The sample size for this study was 400. The data gathering instrument employed for this study was adapted and structured questionnaire. For the purpose of this study, the questionnaire was divided into three sections: Sections A, B and C. Section A consists of personal information about the respondents which includes; gender, age, marital status, and name of deposit money bank, department and hierarchy. Section B consists of statements for work life balance while section C is employee performance. The scales are: 6(Strongly Agree), 5(Agree), 4(Partially Agree), 3Partially Disagree), 2(Disagree) and 1(Strongly Disagree). The reliability was calculated by using the statistical methods such as the Cronbach"s alpha. The reliability index for the Work life balance and Employee performance of selected manufacturing industries in Ogun State, questionnaire was 0.996 for the overall scale. 
Testing of Hypotheses

\section{Result}

\section{Hypothesis One}

$\mathrm{Ho}_{1:}$ Work overload has no significant effect on employees" performance in selected manufacturing industry in Ogun State. The hypothesis was tested by t-test for independent measures. The result is stated in table 4.1 below.

Table 1: Summary of Linear Regression Analysis on Contribution of work overload to Employees' Performance

\begin{tabular}{|c|c|c|c|c|c|c|c|}
\hline \multicolumn{2}{|l|}{ Model } & R Square & \multicolumn{2}{|c|}{ Adjusted R Square } & Std. Error of the Estimate & & \\
\hline 1 & $.338^{\mathrm{a}}$ & .457 & .106 & & 1.09444 & & \\
\hline \multicolumn{2}{|l|}{ Model } & \multicolumn{2}{|c|}{ Sum of Squares } & Df & Mean Square & $\mathrm{F}$ & Sig. \\
\hline \multirow{3}{*}{1} & Regression & \multicolumn{2}{|l|}{21.642} & 2 & 22.752 & 55.767 & $.000^{\mathrm{b}}$ \\
\hline & Residual & \multicolumn{2}{|c|}{230.812} & 473 & 5.675 & & \\
\hline & Total & \multicolumn{2}{|c|}{255.154} & 475 & & & \\
\hline
\end{tabular}

a. Predictors: (Constant), Work overload

b. Dependent Variable: Employees ${ }^{\text {ee }}$ performance

The result in Table 1 revealed that there was a significant contribution of work overload to employees" performance $\left(\mathrm{F}_{[1,473]}=22.752, \mathrm{P}<0.05, \mathrm{R}^{2}=0.0457\right)$. Therefore, hypothesis one was rejected by the result of the study. This implies that work overload has a significant contribution to organizational productivity as eemployee"s performance.

Ho2: Work hours has no significant effect on employees' performance in selected manufacturing industry in Ogun State.

Table 2: Summary of Linear Regression Analysis on Contribution of work hoursto employees' performance

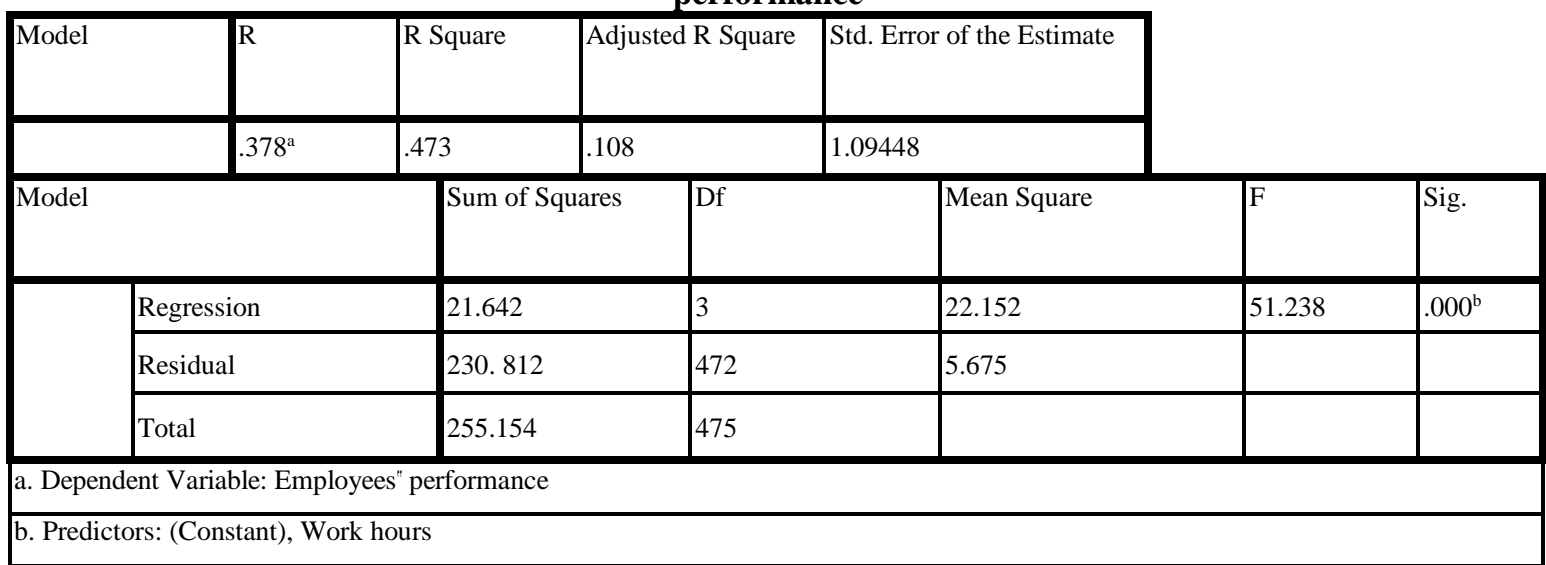

a. Predictors: (Constant), Work hours

b. Dependent Variable: Employees ${ }^{\text {ee }}$ performance

The result in Table 2 revealed that there was a significant contribution of work hours to employees" performance $\left(\mathrm{F}_{[1,472]}=51.238, \mathrm{P}<0.05, \mathrm{R}^{2}=0.0473\right)$. Therefore, hypothesis two was rejected by the result of the study. This implies that work hours have a significant contribution to employees" performance by the respondents.

\section{Discussion of Findings}

The study investigated the effect of work-life balance on employee performance of selected manufacturing industries in Ogun State. Findings of the study revealed there was a significant influence of worklife balance on employee performance. It also revealed that employees are often over loaded with work, which in turns affects their performance within the organization and also affects the organizational productivity. 
Impact of Work Overload and Work Hours on Employees Performance of Selected ..

The finding further revealed that, most employees spend more than the usual stipulated time working and this strongly affects their performance. Employees tend to be more involved in more tasks as a result of low shortage of workers within the organization. This study has shown that work-life balance is an important factor that brings about employee performance. Employeesare productive by their ability to render a "come back again services" to their customer and this is achieved when employees are motivated by the various career development plan and flexible work environment given to them by the organization.Mcnall, Aline and Jessica (2010) investigated the relationship between the availability of two common types of flexible arrangements (flextime and compressed work week), work to family enrichment and, in turn, the relation between work to family enrichment and (a) job satisfaction and (b) turnover intentions. Clare and Deirdre (2010) highlighted an unexpected consequence of adopting flexible working practices. Away from the expected improvement in employee performance due to flexible work options, the researchers presented evidence of work intensification being experienced by employees working reduced hours and employees working remotely. Clare and Deirdre (2010) also presented evidence that employees on flexible working arrangements record higher levels of job satisfaction and organizational commitment than their nonflexible counterparts. While most studies highlight the benefits of flexible working arrangements vis-a-vis employee performance, some scholars have presented evidence of unanticipated reactions to availability of flexible working at organizations. Dex and Smith (2007) for instance, affirmed that a lot of workers do not fancy becoming visible as special cases or requiring special treatment to their colleagues. This perception sometimes hinders such employees from utilizing the available flexible working opportunities which defeats the purpose of such provisions. Allen (2009) stated that co- workers tend to perceive employees who make use of work-life balance programs in organizations as less committed. It is therefore important for organizational leadership to ensure these perceptions are corrected so as to get the best from adopted flexible working practices.Umer and Akram (2011) in their study on investigation of employee retention in industry showed that career development has strong relation with turnover of workers.

\section{Conclusion}

To achieve WLB, every employee should set the goal and excel both in career and family. Some of the strategies and skills at work such as planning, organizing and setting limits can be used at home and work place for accomplishing a satisfying and fulfilling well balanced life both professionally and personally. Low employee morale can negatively impact performance, if employees are stressed and overworked, they may not be able to perform optimally. Employer should consider providing their employee with flexible work options and more control over how their work is done. Also work for the accomplishment of organizational objectives and individual upliftment to satisfy the career needs. Organisations need to adopt human resource strategies and policies to overcome the issues of the work life balance of employees in the current business environment.

\section{Recommendations}

1. Employers should cut meaningless work and streamline time-consuming tasks.

2. Team building, workshops and other social activities should be encouraged. These will help employees" bond and reduce their stress levels. If one of the employees show sign of fatigue and stress, such employee should be encourage to network with other employee. Encourage them to collaborate and distribute their workload evenly.

3. Management should create a flexible working hour for their employees.

4. Employer should make sure they create leisure activities for their employee to ease themselves of stress.

\section{References}

[1]. Abualoush, S., Bataineh, K., \& Alrowwad, A. (2018). The role of knowledge management process and intellectual capital as intermediary variables between knowledge management infrastructure and organization performance. Interdisciplinary Journal of Information, Knowledge, and Management, 13, 279-309.

[2]. Abualoush,S.H.,Obeidat,A.M., Ali, A., Masaedeh,R.,\&Al-Badi,A. (2018a)."The role of employees empowerment as an intermediary variable between knowledge management and information systems on employees" performance". VINE Journal of Information and Knowledge Management Systems, 48(2), 217-237.https://doi.org/10.1108/VJIKMS-08-2017-0050

[3]. Akanji, D. E. (2013). Human resource management: When research confronts theory. International Journal of Human Resource Management, 12(2), 22-38.

[4]. Anitha,J.(2019).Determinants of employee engagement and their impact on employee performance. International Journal of Productivity and Performance Management, 63(3),308-323.https://doi.org/10.1108/IJPPM-01-2013-0008

[5]. Anwar, J., Hansu, S.A.F.,\&Janjua, S.Y. (2019). Work-life balance: What organizations should do to create balance?World Applied Sciences Journal, 24(10), 1348-

[6]. Au,W.C., \&Ahmed, P.K.(2018)."Sustainable people management through work-life balance: a study of the Malaysian Chinese context". Asia-Pacific Journal of Business Administration, 6(3),262-280. https://doi.org/10.1108/APJBA-02-2018-0024

[7]. Breitenecker, R.J.,\&Shah,S.A.M.(2018). Relation of work-life balance, work-family conflict,and family-work conflict with the employee performance-moderating role of job satisfaction.South AsianJournal of Business Studies, 7(1), 129146.https://doi.org/10.1108/SAJBS-02-2017-0018 
Impact of Work Overload and Work Hours on Employees Performance of Selected ..

[8]. Brownlee, R., \&Motowidlo. (2019) Work life balance reflections on employee satisfaction. Serbian Journal of Management, 6 (1) 85 $-96$

[9]. Burke, S.A, \& Peter, N. (2018). The influence of work life balance and job satisfaction on organizational commitment of healthcare employees" ${ }^{e}$. International journal of Human Resource Studies, 4(2), 18-24.

[10]. Clarke, M., Koch, L., \& Hill, E. (2017), "The work-family interface: Differentiating balance and fit", Family and Consumer Sciences Research Journal, 33(2), 121-140.

[11]. Cummings, H. I \&Worley, J. E. (2017) Human resource management: an experimental approach. 2nd ed. Irwin: McGraw Hill Darmawan, D. et al (2020). The Quality of Human Resources, Job Performance and Employee Loyalty, International Journal of Psychosocial Rehabilitation, Vol. 24 Issue 3, 2580-2592

[12]. Emslie, C., \&Hunt, K. (2020). "Live to work or work to live?".The Australian and New Zealand Journal of Organizational Psychology,3, 54-65.

[13]. Erbasi, B, Osman, R \&Tugay, Y. (2018). Association between performance measurement systems and organizational effectiveness International Journal of Operations and Production Management, 34(7), 853-875.

[14]. Ertut, D. \& Funda, C. (2014). Human resource management (8th ed). London: Prentice Hall. London: Prentice Hall

[15]. Faiza,T.A.,\&Nazir, F.S. (2015). Capacity building boost employees performance.Industrial and Commercial Training, 47(2),6166.https://doi.org/10.1108/ICT-05-2014-0036

[16]. Fapohunda, T. M. (2014) An exploration of the effects of work life balance on productivity. Journal of Human Resource Management and Labour Studies, 2(2) 71-89.

[17]. Greenhaus, G.H., \&Allen, T.D. (2017). "Work-family balance: a review and extension of the literature", in Tetrick, L. and Quick, J.C. (Eds), Handbook of Occupational Health Psychology, 2nd ed., American Psychological Association, Washington, DC, pp. 165183.

[18]. Greenhaus, M., \&Beutell, P. (1985) Work-life balance in the New Zealand context, in Waring, M., \& Fouche, C. Managing mayhem: Work-life balance in New Zealand. Wellington, New Zealand: Dumoure Publishing Ltd.

[19]. Grzywacz, J.G.,\&Carlson, D.S. (2007). Conceptualizing work-family balance: implications for practice and research. Advances in Developing Human Resources, 9(4), 455-471.https://doi.org/10.1177/1523422307305487

[20]. Guthrie,V.M.J.(2018). "Management control of work-life balance. A narrative study of an Australian financial institution". Journal of Human Resource Costing \& Accounting, 16(4), 258-280. https://doi.org/10.1108/14013381211317248

[21]. Helmle, J.R., Botero,I.C., \&Seibold,D.R.(2019). "Factors that influence perceptions of work-life balance in owners of copreneurial firms".Journal of Family Business Management, 4(2),110-132.https://doi.org/10.1108/JFBM-06-2019-0013

[22]. Hildebrandt, E. (2016). Achieving a Balance, Ohio Certified Public Accounts Journal, 58(1): $21-22$.

[23]. Hon, A.,\&Chan, W. (2019).“The effects of group conflict and work stress on employee performance". Cornell Hospitality Quarterly, 54(2), 174-184. https://doi.org/10.1177/1938965513476367

[24]. Hudson Resourcing. (2017) The case for work/life balance: Closing the gap between policy and practice. Hudson Australia and New Zealand available on www.hudson.com

[25]. Hye, K. K. (2014) work life balance and employee performance. The mediating role of affective commitment. Global Business Management Research: An International Journal, 6(1), 37-51.

[26]. Joo, B.K., \&Lee,I.(2017)."Workplace happiness: work engagement, career satisfaction, and subjective well-being", Evidence-based HRM.A Global Forum for Empirical Scholarship, 5(2), 206-221.https://doi.org/10.1108/EBHRM-04-2015-0011

[27]. Kelly, R. \& Moen, G. (2017). Work Productivity and Job Satisfaction. New York, university press New York

[28]. Konrad, J. \&Mangel, E. (2016) Literature review of issues related to work-life balance, workplace culture and maternity/childcare issues. Crisis Pregnancy Agency: Summary Report of the Consultation for the Strategy to Address the Issue of Crisis Pregnancy. http://doi.crisispregnancy.ie/pub/Rep3.pdf

[29]. Koubova,V.,\& Buchko,A. A.(2017)."Life-work balance: Emotional intelligence as a crucial component of achieving both personal life and work performance". Management Research Review, 36(7), 700-719.https://doi.org/10.1108/MRR-05-2018-0115

[30]. Laschinger, H, Fineganj. \& Shamain J. (2017). „The impact of workplace empowerment and org trust on staff nurses work satisfaction and organization commitment. Health Care Management Review, 26, 7-23.

[31]. Lavoie, M. (2019). "Post Keynesian consumer theory: potential synergies with consumer research and economic psychology". Journal of Economic Psychology, 25(5), 639-649.https://doi.org/10.1016/j.joep.2003.02.001

[32]. Lawson, K.M., Davis, K.D., Crouter, A.C., \& O"Neill, J.W. (2019). "Understanding work-family spillover in hotel managers". International Journal of Hospitality Management, 33, 273-281. https://doi.org/10.1016/j.ijhm.2012.09.003

[33]. Lee, C. M., Elke, D. \& Dobson, R. D. (2019) „Work-life balance for early career canadian psychologists in professional programs Canadian psychology". Canadian Psychological Association, 50 (2), 73-82.

[34]. Mamedu, C. P., \& Ogwime, S L. (2017) „Work-Family Conflict, Enrichment, and Balance under "Levels" and "Episodes Approaches". Journal of Management, 37(1), 68-98.

[35]. Mukururi, D. S. \& Ngari, A. (2014). Including the social-cultural and policy contexts in our multi-level, Multi-National study of workfamily conflict. Report to the International Workshop. Guelph, ON.

[36]. Mullen, J.,\&Kelloway, E.K. (2018).“Occupational health and safety leadership”, in Quick, J.C. and Tetrick, L.E. (Eds), Handbook of Occupational Health Psychology, 2nd ed., American Psychological Association, Washington, DC.

[37]. Nielsen, K., Randall, R., Yarker, J.,\&Brenner, S.O. (2019).“The effects of transformational leadership on followers ${ }^{\text {ee }}$ perceived work characteristics and psychological well-being: a longitudinal study". Work \& Stress, 22(1),1632.https://doi.org/10.1080/02678370801979430

[38]. Ninijhawan. M, Dhruv, B. T \&Ajay, A. (2015) Impact of work life balance on employees performance an empirical study on seven apparel organization in Sri lanka. Proceedings of the third International Symposium.

[39]. Obeidat,A.M.,Abualoush, S., Irtaimeh, H., Khaddam, A.A.,\&Bataineh, K.(2018), The role of organizationalculture in enhancing the human capital applied study on the social security corporation. International Journal of Learning and Intellectual capital,15(3),258276. https://doi.org/10.1504/IJLIC.2018.094718

[40]. Oduma, O, Caroline, D. E., \& Were, D. (2014) A study of multiple work-life balance initiatives in banking industry in Nigeria. International Research Journal of Finance and Economics. 133,108-109.

[41]. Ogbonnaya N. M., Daniel K., Connolly, K. M., \&Veldhoven. K., (2017) Empirical analysis of work life balance policies and its impact on employee"s job satisfaction and performance: Descriptive statistical approach. American Journal of Theoretical and Applied Statistics.4(2), 33-43.

[42]. Ogbonnaya, J. M, Daniel V, Daniel S. O, \&Veldhoven, J. (2017) Work life balance practices on employee performance of Ecobank Kenya. European journal business and management, 5(25), 179-185.

[43]. Ojo, S. (2018) Work Life Balance Practices and Policies: Managers and Employees Experience in the Nigerian Banking Sector. Brunel Business School - Doctoral Symposium 27th \& 28th March 
Impact of Work Overload and Work Hours on Employees Performance of Selected ..

[44]. Orogbu, H. A, Onyeizugbe, C. T \& Chukwuemeke, E. A. (2015). What does "work-life management" mean in China and Southeast Asia for MNCs? Community, Work and Family, 12(2), 179-196. http://dx.doi. org/10.1080/13668800902778959

[45]. Osisioma, I. S., Nzewi, O. P., \& Ifechi, H. O. (2015) work life balance practices in Nigeria a comparison of three sector journal on competitiveness. Journal of competiveness 6(2), 3-14. DOI: 10.7441/joc.2014.02.01

[46]. Pawirosumaro, S.,Sarjana, P.K.,\&Gunawan, R. (2017)."The effect of work environment, leadership style, and organizational culture towards job satisfaction and its implication towards employee performance in Parador Hotels and Resorts, Indonesia". International Journal of Law and Management, 59(6), 1337-1358. https://doi.org/10.1108/IJLMA-10-2016-0085

[47]. Pawirosumarto,S., Sarjana, P.K., \&Muchtar,M. (2017)."Factors Affecting Employee Performance of PT. Kiyokuni Indonesia".International Journal of Law and Management, 59(4),203-221. https://doi.org/10.1108/IJLMA-03-2016-0031

[48]. Russell, H., O'Connell, P.J., \& McGinnity, F. (2019). "The Impact of Flexible Working Arrangements on Work-life Conflict and Work Pressure in Ireland", Gender, Work and Organization, 16, 73-97.

[49]. Semlali,S.,\& Hassi,A.(2016)."Work-life balance: how can we help women IT professionals in Morocco?".Journal of Global Responsibility, 7(2), 210-225. https://doi.org/10.1108/JGR-07-2016-0017

[50]. Shaffer, M.A., Reiche, B.S., Dimitrova, M., Lazarova, M., Chen, S., Westman, M., \& Wurtz, O. (2016).“Work and family role adjustment of different types of global professionals: Scale development and validation". Journal of International Business studies, 47(2), 113-139. https://doi.org/10.1057/jibs.2015.26

[51]. Shah, L. (2014). The effects of working time on productivity and firm performance. A Research Synthesis Paper: International Labour Organization, Geneva. http://www.ilo.org/public/libdoc/2018/112bo9_172_eng

[52]. Susana,P., \&Ramón,V.C.(2019). "Work-life balance under challenging financial and economic conditions". International Journal of Manpower, 34(8),961-974. https://doi.org/10.1108/JJM-07-2019-0172

[53]. Uddin, I. S., Luva, H. O \&Hossian, C. (2013) Work life balance policies and practices: A case study of Nigerian female university students. European Journal of Business and Management 6 (12), 184-193

[54]. Wang, J. \&Walumbwa, J. (2017). Positive management: Increasing employee productivity. New York, USA: Business Expert Press, LLC.

[55]. Yukhtharamani, S., Roslina, R. \& Roslinah, R. (2014). The constraints of a work life balance approach: An international perspective. The International Journal of Human Resource, 18(3), 360 - 373

[56]. Zhang, O. M. (2018) Principles and practices of public personnel administration: A Nigeria perspective. Onitsha: Perfect Image.

Clement Uchechukwu Ukwadinamor Ph.D, et. al. "Impact of Work Overload and Work Hours on Employees Performance of Selected Manufacturing Industries in Ogun State."IOSR Journal of Business and Management (IOSR-JBM), 22(11), 2020, pp. 16-25. 